\title{
Tendenciák a mesterséges neuron hálók kutatása terén
}

\author{
Szerző: Ferenczi László
}

\section{Összefoglalás}

Ezen dolgozat összefoglalót kíván képezni a mesterséges neuronhálók terén az utóbbi években elért eredményekből. A tudományos élet több területen alkalmazást nyertek a mesterséges intelligenciát alkalmazó módszerek. A szakértő rendszerek mellett ez az a terület ami gyakorlati használhatóságát legjobban bebizonyította.

A neuronhálók müködésében fontos szerepet játszanak olyan speciális tulajdonságok mint az öntanulás, asszociáció. Dolgozatom első részében az elörecsatolt hálók müszaki alkalmazás szempontjából lényegesebb típusait ismertetem, majd a versengő hálók egy szűkebb csoportjára fogok kitérni. Befejezésül néhány az utóbbi években elért eredmény müszaki területen való alkalmazhatóságát fogom megvizsgálni. Ezzel egy összefoglaló képet szeretnék adni a neuronhálók föbb típusainak alkalmazási lehetőségeiről.

\section{Biológiai alapok}

A legtöbb hálótípusban a neuronmodell hasonló a biológiai neuronhoz. Az emberi agy egy komplex biológiai neurális hálózat, amely idegsejtek, neuronok sokaságát tartalmazza. Az idegi müködés a félvezetők kapcsolási sebességéhez képest lassú, de a fejlett párhuzamos mủködés miatt nagy teljesítményü. A tanulás nem más, mint a neuronok közötti súlyok beállítása. A tanulás lehet felügyelt vagy felügyelet nélküli. ( önszervezödö )

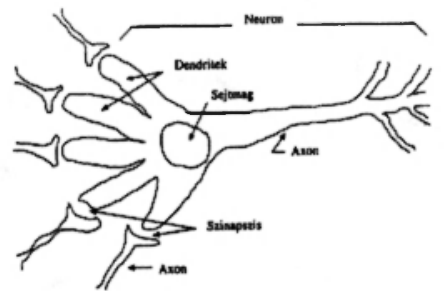

l.ábra

Egy idegsejt

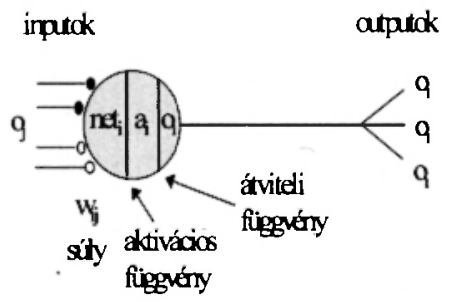

2.ábra

Mesterséges neuron

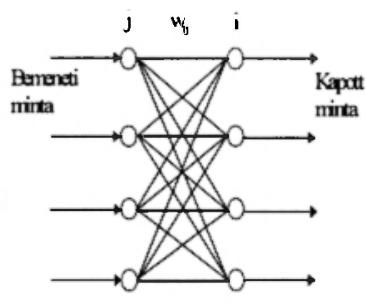

3.ábra

Kétrétegü perceptron

\section{Mesterséges neuron és a pereeptron}

A mesterséges neuron volt az első mesterséges idegsejt modell, számítógép nélküli megvalósítảsban. Jelentősége mégis nagy mivel a később kifejlesztett modellek alapjául szolgált. Erre a kezdetleges modellre építve készült el a két rétegủ perceptron, amely az elemi mesterséges neuronokat két egymással kapcsolatban lévő rétegbe rendezi. Az első réteg a bemeneti a második a kimeneti réteg szerepét tölti be. $\mathrm{Az}$ elemi neuronok a küszöb átviteli függvényt használják. A tanítás során a súlyokat úgy kell 
változtatni, hogy az egymással kapcsolatban lévő aktív neuronok között a kapcsolat erősödjön. Ez a Hebb féle tanulás.

A háló hibájának róható fel hogy hasonló minták esetén gyakori a tévesztés. Ezeket hibákat a backpropagation hálók javították ki.

\section{Backpropagation}

Ezt a neurális hálót gyakran szokták többrétegü perceptronnak nevezni. A backpropagation egy többrétegü hálózat. Tipikusan 3 vagy 4 réteget szoktak alkalmazni. A perceptron modell nem volt képes a kizáró vagy müvelet megtanulására, de a rejtett réteg megjelenésével a backpropagation háló már képes erre. Az XOR müvelet jelentős elöre lépés volt a perceptronhoz képest. A hálózatot itt is minták alapján tanítjuk. A súlyokat a hibák alapján az általánositott delta szabály szerint módosítjuk úgy, hogy a hálózat kimenetén a hiba kisebb legyen, a minta újbóli tanításakor.
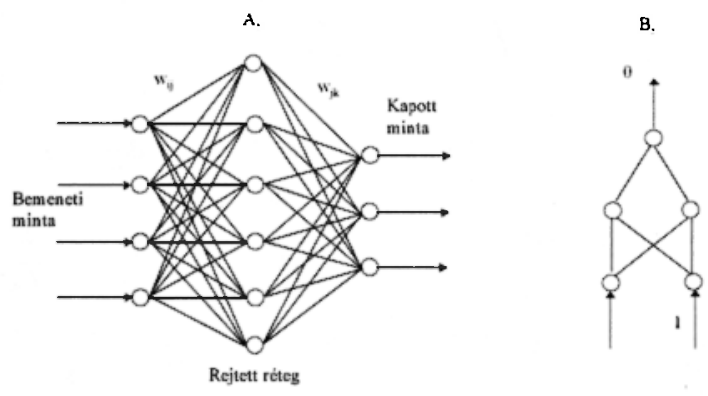

4.ábra

Backpropagation háló (A) és a kizáró vagy mủvelet (B)

\section{Furat megmunkálás müveleti sorrendjẻnek tervezése backpropagation neuron hálóval}

Backpropagation neurális hálózatot alkalmazó szoftverek egyik képviselöje a Brainmaker nevezetủ program. Néhány éve egy tudományos kutatás keretén belül vizsgálták a müszaki területen való alkalmazhatóságát.[6,7]

Erre az egyik példa a hengeres furatok technológiai paramétereinek becslése, amelynek során a használt algoritmusok nem voltak képesek a technológia váltások határán elhelyezkedő megmunkálások között átmenet képzésére. Például egy tengely végén elhelyezkedő $25 \mathrm{~mm}$ átmérőjủ furat, ami az algoritmus szempontjából „közepes furatnak” számít, amíg a tỏle $0,5 \mathrm{~mm}$-rel kisebb, 24,5 mm-es furat még „kis furatnak” tekinthető és már minőségileg tér el a $0,5 \mathrm{~mm}$-rel nagyobb társától. A példánál maradva mondhatjuk a $25 \mathrm{~mm}$ névleges átmérőjủ furatot „kicsit jobb” megmunkálni $\mathrm{X}$ módon, mint az ugyanolyan feltételek közötti $24,5 \mathrm{~mm}$ átméröjüt, illetve elmondhatjuk, hogy erre már a $\mathrm{Z}$ müveletsor „kicsit alkalmasabb” lenne. Semmiképpen sem állíthatjuk azt, hogy X igen, $Z$ pedig egyáltalán nem alkalmazható, ezzel szemben jelenleg ilyen merev algoritmusok müködnek szinte minden rendszerben. Létrehoztak egy olyan rendszert, amely képes volt a fenti határok összemosására és az eredményt valószínüségi súlyozással együtt szolgáltatta. Ez a rendszer a Brainmaker programon alapul, amely a backpropagation neuronhálót használja. A furat megmunkálással kapcsolatban két kísérlet történt. Az első esetén háló bemeneti adataiként a furat átmérő, furat pontossági osztálya, érdességi osztálya, míg kimenetként a furat megmunkálási sorrendje szolgált. Ebben az esetben a betanítás bináris jellegü (kizárásos) volt, ami azt jelenti, hogy a kimenetek közül mindig csak egyet tekintünk aktívnak, az összes többi passzív állapotban volt. Azaz egy megadott bemeneti mintára csak egy kimenetet aktivált. Míg a második esetben egy kicsit másképp történt. Itt a neuronháló a bementi adatokból csak a következő szükséges müvelet típusát állapította meg, és csak már furatos előgyártmányok szerepeltek bemenetként. Egy input vektor egyidejüleg több kimenetet is aktiválhatott. A felépített és betanított hálót ezek után egy ellenőrzésnek vetették alá, ami három részböl állt. Az elsőben a tesztadatokkal futtatva a betanított hálózatot a jó és rossz válaszok aránya jellemezte a betanítás hatékonyságát, minőségét. A második 
módszernél lehetöségünk volt egy-egy kimeneti neuron kiválasztására, $s$ a tesztelő eljárás megmutatta, hogy a kiválasztott output neuron gerjesztettsége mely input neuronoktól és milyen mértékben függ. A harmadik tesztelési lehetőség a bemeneti neuronok valamelyikének lineáris változtatott gerjesztése, midőn a többi aktuális gerjesztettségü maradt. Eközben lehetőségünk volt bármelyik kimeneti neuron gerjesztettségi állapotának figyelésére is. Itt ez különösen alkalmas ellenörzési módszer, hiszen éppen a furatátmérő változásának hatására van szükségünk. Mind a két esetben használhatónak bizonyult a backpropagation neuron háló.

\section{Hátracsatolt neuronháló modellek}

A hátracsatolt modelleknél az input réteg neuronjai felöl nemcsak elöre, az output réteg neuronjai felé halad az inger, hanem visszafelé is. Így egy neuron kimenete visszacsatolódik egy megelöző réteg neuronjára, ezáltal a visszacsatolt neuron bemenetének értéke függhet a korábbi kimeneti értéktől.

\section{Hopfield Féle Neuron háló}

A Hopfield háló egyrétegü neuronhálózat, amelyben minden neuron kimenete a többi elem bemenetére a beállítható súlyozással van visszacsatolva. Ez az egyetlen neuron réteg, inputként és outputként is szerepel. A neuronok kapcsolata szimmetrikus. A hálózat tanítását a módosított Hebb szabály alapján végezzük. A Hopfield háló esetében alkalmazott módosított szabály a súlyok erősségét növeli vagy csökkenti annak megfelelöen, hogy a két neuron kimenete megegyező vagy különbözö állapotú. A hálót elsősorban bináris minták tárolására, illetve a tárolt képek hiányos változatainak felismerésére lehet használni. Jelentős alkalmazási területe még az optimalizációs problémák megoldása. Nevezetes alkalmazása az utazóügynök feladat megoldása(a városok mindegyikét egyszer és csak egyszer érintő legrövidebb körút megadása).

\section{Kétszintü folyamatoptimálási lehetőség Hopfield féle neuronháló segítségével}

Optimálási problémánál elsődleges feladatunk a célfüggvény megválasztása. Egyöntetü cél a mai vállatok tervezési rendszerében, hogy a gyártási folyamatnak a rendelkezére álló erőforrások figyelembevételével, az előirt minőség betartásával minimális anyag, energia, idő, stb. ráfordítása legyen. Cél a gyártási költségek minimalizálása. A gyártási költségek alapvetően két csoportra bonthatók: a munkadarabok konkrét megmunkálásával kapcsolatos és a megmunkálások közötti átmenetekkel kapcsolatos költségekre. A kétszintü optimálás lényege: az elsỏ szinten felületenként kiválasztjuk a müveleti költségek szempontjából optimális megmunkálásokat, majd a második szinten ezeket a megmunkálásokat úgy rendezzük sorba hogy az átmeneti költségek összege minimális legyen. A két szinten felmerülő problémákról a következőket állapíthatjuk meg. Az első szint „legrövidebb út” problémája nem jelent nehézséget, ellentétben a második szinttel ami az operációkutatásból ismert

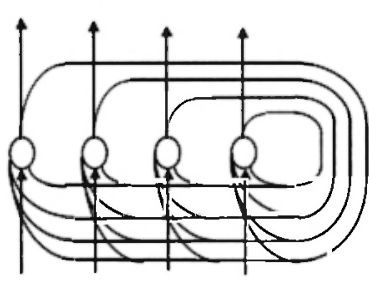

5.ábra

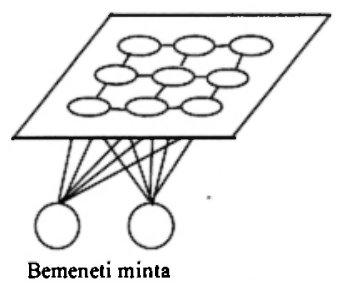

6.ábra

Hopfield háló „utazó ügynök probléma" technológiai tartalmú analógiája. Ez a probléma az NP-teljes problémák csoportjába tartozik, azaz nagy valószinüséggel nem létezik olyan algoritmus, amely nagyméretủ feladatok megoldását elfogadható futási idővel szolgáltatná. Az utazó ügynök problémára a feladat megoldása során szigoritó feltételeket teszünk. A feladat megoldására több lehetőségünk van. Úgymint: teljes leszámlálás, eredeti utazó ügynök feladat megoldásának átalakítása, speciális egzakt módszerek, heurisztikus algoritmusok.[4,7] Az eredeti utazó ügynök feladatot az említett Hopfield - féle neuron háló segítségével is meghatározható. 
A Hopfield modell egy 10 várost tartalmazó feladat esetén 20 futtatás során 16-szor konvergál a lehetséges körúthoz, ebböl 8 a legjobb körutat adja meg 181.440 lehetséges körút közül.

\section{Kohonen neuron háló modell}

Az önszervező hálózat a bemeneti minták topologikus leképezését végzi el: a minták olyan rendezését, amelynek során az egymáshoz közeli minták egymáshoz közeli osztályokba kerülnek. Az egyrétegü hálózat a bemeneti tároló elemeit a súlyokon keresztül egy kétdimenziós hálóra vetíti, ahol a neuronok egymással versengve, a legerősebb neuront kijelölve választják ki, hogy melyik neuron fogja a kijelölt mintát reprezentálni.

\section{Alkatrészcsaládok és gépcsoportok képzése}

A csoport technológiát jellegzetesen a kis és közepes gyártási tételszám esetén használható. Három módszer ismert a technológiai csoportok kialakitásához: az alakszerinti csoportosítás, osztályozás és kódolás és termelési folyamat elemzése. Ez utóbbihoz kapcsolódóan ismert a mátrix manipulációs módszer. Ezen eljárás elönye, hogy elkerüli a szubjektív és komplex osztályozási elveket. A módszer egy olyan mátrixon alapul amelynek vizszintes sorai a szerszámgépek a függöleges sorai az alkatrészekre vonatkoznak. A mátrix $x_{i j}$ elemei egyenlök eggyel ha az i. gép szükséges a $\mathrm{j}$. alkatrész megmunkálásához és nulla ha ez nem igaz. Nagy méretü mátrixok esetén a sok szükkereszt metszet miatt nehéz ezeket a mátrixokat használni. Az önszerveződő neuron hálók képesek a mintákban rejlö hasonlóság felismerésére. Ezt a tulajdonságot használhatjuk az alkatrészcsaládok és gépcsoportok azonositására a gép elöfordulási mátrix alapján. Két megközelítés volt a leglényegesebb: a Kohonen modellen és az ART1 hálón alapuló. A gépcsoportok és alkatrészcsaládok kialakítását a háló stabil állapotában a súlymátrix alapján tehetjük meg. Az alkatrész osztályok száma a betanítás kezdetén ismeretlen, így csak kevés számú output neuront használhatunk. A stabil állapot beállta után a kimeneti neuronok számának változtatása nincs hatással az eredményre. A neuron hálók osztályozó képessége kiaknázható a csoport technológiai problémák megoldásához.

Irodalom

[1]. R. Beale and T. Jackson: Neural Computing: An Introduction, Adam Hilger, Bristol, 1990.

[2]. Dr. Dudás László: Mesterséges intelligencia módszerek I-II , Oktatási segédlet, Miskolc,1995.

[3]. César O. Malavé - Satheesh Ramachanran: Machine-part family formation Artificial Neural Networks for Intelligent Manufacturing, Edited by Cihan H. Dagli, Chapman \& Hall 1994.

[4]. Eszes László: Szakaszos technológiai folyamatok optimálása szigorított „utazó ügynök” feladatra visszavezetett módszerrel, Gépgyártástechnológia, XXVII évfolyam, 8.szám, 1987. augusztus

[6]. Jeanette Lawrence: Introduction to Neural Networks California Scientific Software, Grass Valley, 1991.

[7]. Mádai A. - Dr. Vadász D.: A Brainmaker neuronhálós AI program rendszer adaptációs lehetőségeinek feltárása méretes szerszámokkal végzett furat megmunkálások kiválasztásához, Kutatási jelentés, Miskolci Egyetem, 1991.

[7]. Mádai Attila: Mesterséges neurális hálózatok müszaki alkalmazhatóságának vizsgálata, Kutatási jelentés, Miskolci Egyetem, 1992.

[8]. Dr. Tóth Tibor: Automatizált müszaki tervezés a gépgyártástechnológiában, Egyetemi jegyzet, Miskolc, 1994.

Ferenczi László doktorandusz,

Miskolci Egyetem, Alkalmazott Informatika Tanszék, Miskolc - Egyetemváros 3515, Tel: +3646-365-111/19-52, +36-30-585-580, E-mail: ferenczi@iit.uni-miskolc.hu 